\title{
Cystic Fibrosis: Lysosomal and Mitochondrial Enzyme Activities of Lymphoid Cell Lines
}

\author{
Irena Antonowicz, Wolfgang G. Sippell, and Harry Shwachman ${ }^{[43]}$
}

Division of Clinical Nutrition, Department of Medicine, The Children's Hospital Medical Center, and the Department of Pediatrics, Harvard Medical School, Boston, Massachusetts, USA

\section{Extract}

Seven lysosomal enzymes and three mitochondrial enzymes were studied in cultured lymphoid cells from four patients with cystic fibrosis, three heterozygotes, one borderline patient, and six healthy controls. The lysosomes and mitochondria were isolated by differential and density gradient centrifugation. The activity of $\alpha$-glucosidase, which is a lysosomal enzyme degrading glycogen, showed a marked increase in activity in the lysosomes of cultured lymphoid cells obtained from patients with cystic fi brosis as compared with the healthy controls. Two substrates were used for measuring the activity of this enzyme, the synthetic $p$-nitrophenyl- $\alpha$-glucoside ( $p$-NP- $\alpha$ glucoside), and the physiologic substrate glycogen. The values obtained with $p-\mathrm{NP}-\alpha-$ glucoside were $32.6(\mathrm{sD} \pm 8.6)$ and $13.8(\mathrm{sD} \pm 12.2) \mu$ moles $/ g$ lysosomal protein $/ \mathrm{hr}$ and with glycogen $543.5(\mathrm{SD} \pm 163.3)$ and $188.6(\mathrm{SD} \pm 156.3) \mu$ moles/g lysosomal protein/hr for patients with cystic fibrosis and controls, respectively. The values of $\alpha$-glucosidase in the heterozygotes were also elevated, 17.2 ( $\mathrm{sD} \pm 5.5$ ), controls 13.8 ( $\mathrm{sD} \pm 12.2$ ) using $p$-NP- $\alpha$-glucoside as substrate. When glycogen was used as substrate, the values were $226.7(\mathrm{SD} \pm 85.3)$ in the heterozygote and $188.6(\mathrm{SD} \pm$ 156.3) $\mu$ moles/g lysosomal protein $/ \mathrm{hr}$ in the control. The activities of the other six lysosomal enzymes- $\beta$-glucosidase, $\beta$-galactosidase, $\beta$-glucuronidase, $N$-acetyl- $\beta$ glucosaminidase, aryl-sulfatase, and acid phosphatase-were the same in patients with cystic fibrosis as in the controls. The three mitochondrial enzymes assayed, succinic dehydrogenase, glutamic dehydrogenase, and malic dehydrogenase, showed the same activity in all subjects tested.

\section{Speculation}

This study indicates that the metabolism of lymphoid cells obtained from patients with cystic fibrosis $(\mathrm{CF})$ and maintained in culture for prolonged periods differs from that of cells of healthy controls. The abnormally elevated activity for $\alpha$-glucosidase in lymphoid cells derived from patients with cystic fibrosis is noted when measured with synthetic substrate as well as with a physiologic substrate, glycogen. To date no defect in glycogen metabolism has been noted in cystic fibrosis although Pallavicini et al. did observe an increase in the glycogen content of cultured fibroblasts obtained from patients with cystic fibrosis. Bartman et al. found an increase in size of lysosomes in cultured fibroblasts from patients with CF by electron microscopy. These and our observations suggest the possibility of an impaired cellular metabolism in CF indicating that we may be dealing with a lysosomal disorder. Of some importance is the 
observation that the activity of $\alpha$-glucosidase is also elevated in the heterozygote, but not to the same extent as in the homozygote. Perhaps this could offer a means of detecting the heterozygote, a possibility which should appeal to the genetic counsellor. Although numerous techniques and reports have suggested methods of identifying the heterozygote, none is practical or reliable. To be of value the test would have to take less time than required in the technique used here. For this purpose we are in the process of studying the activity of the $\alpha$-glucosidase from cells derived from the patient rather than from cells grown in continuous culture.

It is quite possible that patients suffering from malignant disorders or those receiving radiation or drugs may also show abnormal levels of lysosomal enzymes but may not have the same specificity; i.e., many of the lysosomal enzymes may be elevated rather than an isolated one.

\section{Introduction}

Cystic fibrosis is an inherited, autosomal, recessive disease characterized by abnormalities of the mucous and sweat-secreting glands. The primary defect, however, remains undiscovered. Recent advances in cell culture techniques have made possible the study of this disease on a cellular level. Abnormalities have been recognized in tissue culture fibroblasts from such patients, as well as from heterozygotes [8]. Bartman et al. [2] studied the ultrastructure of cultured fibroblasts and found that the cells from four patients with $\mathrm{CF}$ had an increase in the number and size of lysosomes concomitant with a simultaneous increase in the amount of material stored within these subcellular particles. These findings suggested the possibility of an impaired cellular metabolism in cystic fibrosis which might be reflected in altered enzyme activities with possible changes in intermediary metabolites in subcellular fractions such as lysosomes and mitochondria.

The ability to isolate and establish permanent cell lines from peripheral blood lymphocytes has provided the tools necessary to grow sufficiently large quantities of cells to make such studies of subcellular organelles feasible. In previous studies [17], in which monolayer cultures were employed, it was found that homogenates of cultured fibroblasts from the skin of patients with cystic fibrosis showed no change in several lysosomal hydrolases, namely $\beta$-galactosidase, $\beta$-glucuronidase, aryl sulfatase, and acid phosphatase. Since this investigation had been carried out on whole homogenates of cells, it was possible that an actual lysosomal enzyme abnormality might be obscured by a number of interfering effects caused by other intracellular components. To eliminate those interferences, the present study deals with isolated lysosomes and mitochondria.

The activities of seven lysosomal enzymes ( $\alpha$-glu- cosidase [EC. 3.2.1.20], $\beta$-glucosidase [EC. 3.2.1.21], $\beta$-galactosidase [EC. 3.2.1.23], $\beta$-glucuronidase [EC. 3.2.1.31], $N$-acetyl- $\beta$-glucosaminidase [EC. 3.2.1.30], aryl sulfatase [EC. 3.1.6.1], and acid phosphatase [EC. 3.1.3.2]) and three mitochondrial enzymes (succinic [EC. 1.3.99.1], glutamic [EC. 1.4.1.2], and malic [EC. 1.1.1.37] dehydrogenases) were investigated in isolated lysosomes and mitochondria from established lymphoid cell lines obtained from patients with cystic fibrosis, heterozygotes, clinically healthy individuals, and one patient considered as "borderline" cystic fibrosis.

\section{Materials and Methods}

\section{Patients}

The four patients with $\mathrm{CF}$ were 7, 12, 19, and 22 years of age with an equal sex distribution. The borderline patient was a male 16 years of age and the heterozygotes were parents of CF children, aged 34,41 , and 46 years. Five healthy controls consisted of three males and two females between 20 and 55 years of age. One control, age 20, had had infectious mononucleosis and was well at the time of obtaining the specimen. The majority of cultures were taken between March 1970 and February $1971[40]$.

\section{Lymphoid Cell Lines}

All the cell lines utilized in these studies were derived from peripheral blood buffy coats [19]. All of the cell lines were composed of cells which grow readily in suspension culture and have the morphology of lymphoblasts. Cells to be used for the isolation of subcellular organelles were grown as active suspension cultures in Erlenmeyer flasks. The growth medium was Eagle's minimal essential medium modified for suspension culture [10] and supplemented with "nonessential" amino 
acids [18], sodium pyruvate ( $1 \mathrm{~mm}$ ), and $10 \%$ whole fetal bovine serum. Actively dividing cultures were used throughout these studies.

\section{Preparation of Subcellular Organelles}

Six to $10 \times 10^{8}$ cells were harvested by centrifugation $(100 \times g, 20 \mathrm{~min})$ at room temperature. A modification of the techniques of Rahman and Lindenbaum [25] and Hogeboom [14] was used to prepare the organelles. The cells were resuspended uniformly by use of a PotterElvehjem homogenizer (Teflon-glass) in about $80 \mathrm{ml}$ $0.25 \mathrm{~mm}$ sucrose solution containing $10 \mathrm{~mm}$ triethanolamine (TEA) and $2 \mathrm{~mm}$ ethylenediaminetetraacetic acid (EDTA) tetra sodium salt, $\mathrm{pH}$ 7.4. The cells were disrupted using the nitrogen decompression method described by Hunter and Commerford [15] in a nitrogen bomb [31]. This method was chosen because cells derived from $\mathrm{CF}$ patients and the borderline patient could not be broken by mechanical means (Potter-Elvehjem homogenizer with rotating pestle) without damaging subcellular particles. The nitrogen pressure was applied for $15 \mathrm{~min}$ at $900 \mathrm{psi}$ on $\mathrm{CF}$ and borderline cells and 750 psi on control and heterozygote cells. Higher pres- sures were required to rupture the cells from the CF line and from the borderline case than from the control lines. Under these conditions, more than $90-95 \%$ of the cell membranes were found broken when examined microscopically. Differential and density gradient centrifugations were carried out (details are given in Fig. 1) in a refrigerated centrifuge [32] and in an ultracentrifuge [33], respectively. Linear sucrose density gradients $(10-30 \%, \mathrm{w} / \mathrm{v})$ were generated by mixing 2 and $50.5 \%$ sucrose media (10 mm TEA + 2 mm EDTA, pH 7.4) in a density gradient former [34]. The supernatant from the final centrifugation containing the lysosomes was carefully aspirated off. The mitochondrial sediment was resuspended in sucrose solution. Both fractions were centrifuged at $100,000 \times g$ for $20 \mathrm{~min}$. The resulting pellets were resuspended in $5 \mathrm{ml}$ double-distilled water and disintegrated by gentle ultrasonification [35] ( $4 \times 10 \mathrm{sec}, 40 \mathrm{mv}$ output energy, microtip). All steps were carried out at $4-6^{\circ}$. The lysosomal and mitochondrial homogenates as well as an aliquot of the whole cell homogenate were kept frozen at $-20^{\circ}$ in small quantitites. All determinations were carried out after a single thawing of the sample.

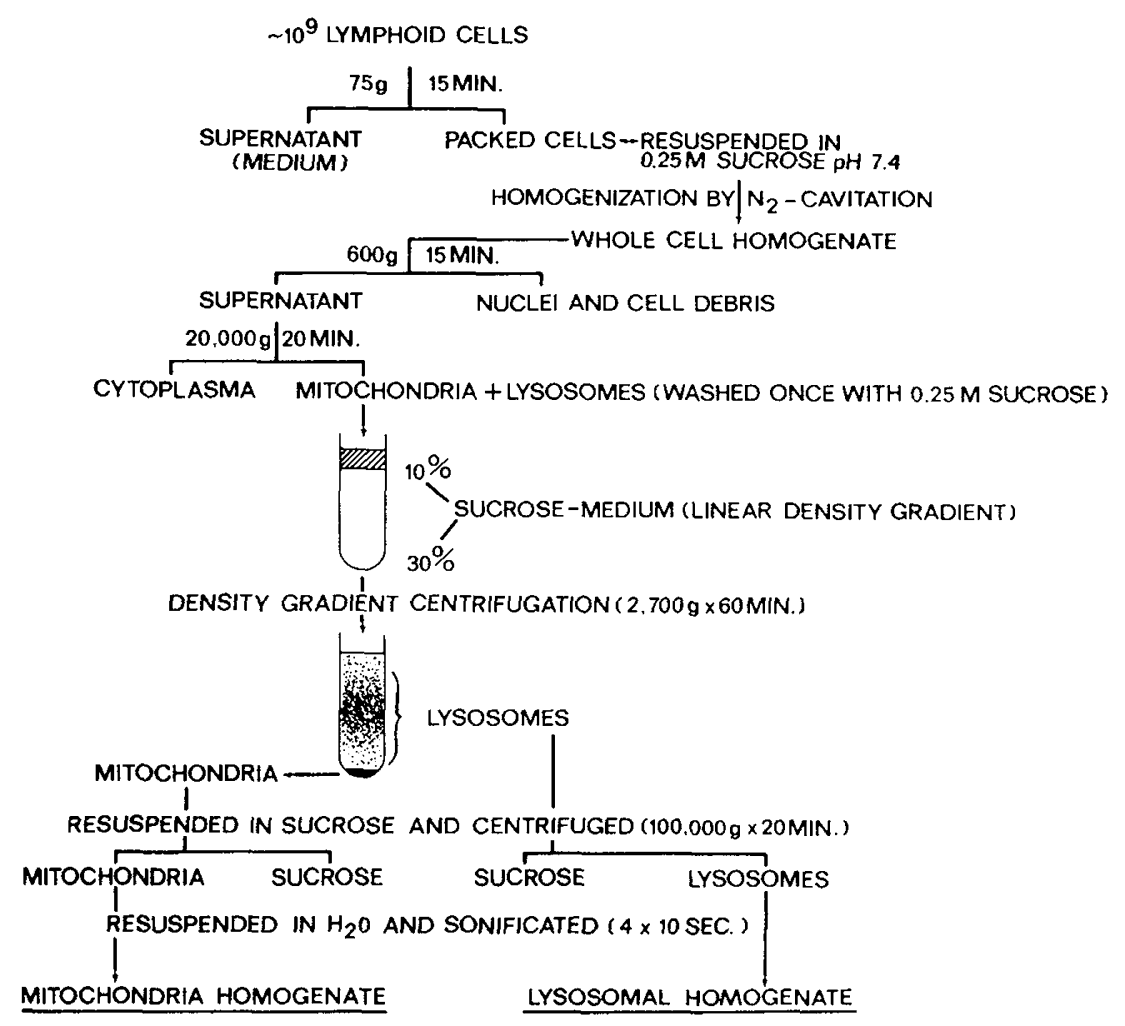

Fig. 1. Preparation of lysosomal and mitochondrial fractions from cultured lymphoid cells. 


\section{Enzymatic Assays}

\section{Lysosomal Enzymes}

$\alpha$-Glucosidase was measured using two different substrates: 1) $p$-nitrophenyl- $\alpha$-D-glucoside and 2) glycogen. The method of Torres and Olavarria [30] was modified by substituting $p$-nitrophenyl- $\alpha$-D-glucoside ( $p$-NP- $\alpha$-gluc) for $\alpha$-phenylglucoside. The incubation mixture contained $0.100 \mathrm{ml} 50 \mathrm{~mm}$ acetate buffer, $\mathrm{pH} 4.0 ; 0.100 \mathrm{ml}$ $30 \mathrm{~mm} p$-nitrophenyl- $\alpha$-D-glucoside [36]; and $0.100 \mathrm{ml}$ lysosomal homogenate. The mixture was incubated at $37^{\circ}$ for $120 \mathrm{~min}$, and the reaction was stopped by adding $0.100 \mathrm{ml} 40 \%$ trichloroacetic acid (TCA) and then centrifuged at $2800 \mathrm{rpm}$ for $15 \mathrm{~min}$. Then $0.200 \mathrm{ml}$ supernatant was pipetted into a small test tube to which $0.300 \mathrm{ml} 2 \mathrm{~N} \mathrm{NaOH}$ was added. The color was read at $420 \mathrm{~m} \mu$ in microcuvettes. Standards of nitrophenol were run simultaneously with the samples. When glycogen was used as substrate, the incubation mixture consisted of $0.200 \mathrm{ml} 50 \mathrm{~mm}$ acetate buffer, $\mathrm{pH} 4.0 ; 0.200$ $\mathrm{ml} 10 \mathrm{mg} / \mathrm{ml}$ glycogen solution [37]; and $0.100 \mathrm{ml}$ lysosomal homogenate. The mixture was incubated for 120 min at $37^{\circ}$. The reaction was stopped by immersing the tubes in boiling water for $2 \mathrm{~min}$. Since the solution was turbid, precipitated protein was centrifuged at $2800 \mathrm{rpm}$ for $15 \mathrm{~min}$. Then $0.100 \mathrm{ml}$ supernatant was used for glucose determination with glucostat special [32] according to the method of Dahlqvist [7]. The color was read at $420 \mathrm{~m} \mu$.

Determinations of $\beta$-glucosidase, $\beta$-galactosidase, and $N$-acetyl- $\beta$-glucosaminadase, in which in each instance liberated $p$-nitrophenol was measured, were based on Beck and Tappel's method [3] modified for microdetermination. The conditions for each determination were as follows: $0.100 \mathrm{ml} \mathrm{McIlvaine's} \mathrm{citrate-phosphate} \mathrm{buffer,}$ $0.100 \mathrm{ml}$ substrate, and $0.100 \mathrm{ml}$ lysosomal homogenate were incubated at $37^{\circ}$ for $30-60 \mathrm{~min}$. The reaction was stopped with $0.100 \mathrm{ml} 40 \%(\mathrm{w} / \mathrm{v})$ trichloroacetic acid and then centrifuged. Then $0.200 \mathrm{ml}$ supernatant was transferred into small test tubes and $0.300 \mathrm{ml} 2.0 \mathrm{~N} \mathrm{NH}_{4}$ $\mathrm{OH}(\mathrm{pH}$ 10.7) was added for color development. The absorbance was read at $420 \mathrm{~m} \mu$. The substrates and the $\mathrm{pH}$ of buffer for each of the enzymes were as follows: $\beta$-glucosidase: $1 \mathrm{~mm} p$-nitrophenyl- $\beta$-D-glucopyranoside [37], pH 5.0; $\beta$-galactosidase: $1 \mathrm{~mm} p$-nitrophenyl- $\beta$-Dgalactopyranoside [37], $\mathrm{pH} 3.0 ; N$-acetyl- $\beta$-glucosaminidase: $2.4 \mathrm{~mm} p$-nitrophenyl- $N$-acetyl- $\beta$-glucosaminide [37], $\mathrm{pH}$ 4.2. With each determination, suitable standards of $p$-nitrophenol were run.

$\beta$-Glucuronidase was measured using a modified method for microdetermination described by Talalay et al. [29]. The substrate used was $0.025 \mathrm{ml} 12.5 \mathrm{~mm}$ phenolphthalein- $\beta$-glucuronic acid [37], with $0.200 \mathrm{ml}$ $100 \mathrm{~mm}$ acetate buffer, $\mathrm{pH} 4.5$, and $0.025 \mathrm{ml}$ lysosomal homogenate. The reaction was stopped after $1 \mathrm{hr}$ incubation with $0.25 \mathrm{ml} 400 \mathrm{~mm}$ glycine-NaCl-NaOH buffer,

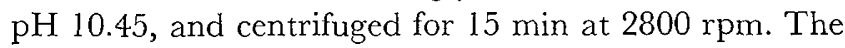
color of the supernatant was read at $540 \mathrm{~m} \mu$. Suitable phenolphthalein standards were run with each determination.

Aryl sulfatase was determined by a modification of the methods of Roy [26] and Bowers et al. [5]. The incubation mixture contained $20 \mathrm{~mm}$ nitrocatechol sulfate dipotassium salt [37]; $50 \mathrm{~mm}$ acetate buffer, pH 5.0; lysosomal homogenate, $0.050 \mathrm{ml}$ in a final volume of $0.500 \mathrm{ml}$. The incubation time was $120 \mathrm{~min}$. The reaction was stopped by adding $1.5 \mathrm{ml} 2.2 \%$ TCA. After centrifugation at $2800 \mathrm{rpm}$ for $15 \mathrm{~min} 1.0 \mathrm{ml}$ supernatant was transferred into a small test tube and $0.25 \mathrm{ml}$ $5 \mathrm{~N} \mathrm{NaOH}$ was added to develop the color which was read in microcuvettes at $540 \mathrm{~m} \mu$. Standards of nitrocatechol were run with each determination.

The acid phosphatase was determined by the modified method of Linhardt and Walter [20]. The incubation mixture consisted of $50 \mathrm{~mm}$ citrate buffer, $\mathrm{pH} 4.8 ; 5.5$ $\mathrm{mm}$ p-nitrophenylphosphate [37]; and $0.050 \mathrm{ml}$ lysosomal homogenate in a final volume of $0.500 \mathrm{ml}$. The mixture was incubated at $37^{\circ}$ for $30 \mathrm{~min}$ in an agitated water bath and then stopped by adding $2.0 \mathrm{ml} 0.1 \mathrm{~N}$ $\mathrm{NaOH}$. The color was read at $405 \mathrm{~m} \mu$; $p$-nitrophenol standards were run parallel with the samples.

In all the enzyme determinations sample blanks were run simultaneously in which the lysosomal homogenate was added after incubation and stopping the reaction. The absorbance was read against the blank in a double beam spectrophotometer [39]. The enzymatic activities are expressed as micromoles of hydrolyzed substrate per gram or milligram of lysosomal protein per hour.

\section{Mitochondrial Enzymes}

Succinic dehydrogenase (SDH) activity was determined according to the method of Arrigoni and Singer [1], modified for measurement in a recording double beam spectrophotometer. A reference reaction mixture was used in which the substrate was substituted by $\mathrm{H}_{2} \mathrm{O}$ to obtain a linear reaction. Malic dehydrogenase $(\mathrm{MDH})$ and glutamic dehydrogenase $(\mathrm{GluDH})$ activities were measured by the method of Bücher et al. [6], who used the modification introduced by Frieden [12]. Mitochondrial enzyme activities are expressed as micromoles 
of either oxidized or reduced substrate per milligram mitochondrial protein per minute.

The protein content of the cellular, lysosomal, and mitochondrial homogenates was determined by the modified methods of Lowry et al. [21] and Eggstein and Kreutzer [11].

\section{Results}

The specific activities of seven lysosomal enzymes in isolated lysosomes of cultured lymphoid cells from six controls, four patients with cystic fibrosis, three heterozygotes and one borderline CF patient are shown in Table I. The values listed were obtained as an average of four to six individual subcultures and cell fractionations in each cell line. The activity of $\alpha$-glucosidase was determined using two substrates, namely the synthetic $p$-nitrophenyl- $\alpha$-glucoside and glycogen. A comparison between the mean value of the activities of the lysosomal enzymes with the recording of one standard deviation, the range of values, and the total number of determinations from which the mean was determined is shown in Table II. The specific activity of $\alpha$-glucosidase is markedly higher with both substrates in the CF group, although individual values from controls overlap the cystic fibrosis group. No differences were found in the remaining six lysosomal enzymes. The specific activity of all the lysosomal enzymes were found to be highest in lysosomes obtained from the patient with borderline cystic fibrosis.

Table III presents the average activities of three mitochondrial enzymes ( $\mathrm{MDH}, \mathrm{SDH}$, and $\mathrm{GluDH}$ ) in isolated mitochondria from cultured lymphoid cells obtained from patients with cystic fibrosis, heterozygotes, borderline, and controls. No marked differences were found.

Two lysosomal enzymes, namely $\alpha$-glucosidase and

Table I. Specific activities of lysosomal enzymes in isolated lysosomes from cultured lymphoid cells, obtained from four patients with cystic fibrosis $(\mathrm{CF})$, three heterozygotes, one borderline, and six control subjects ${ }^{1}$

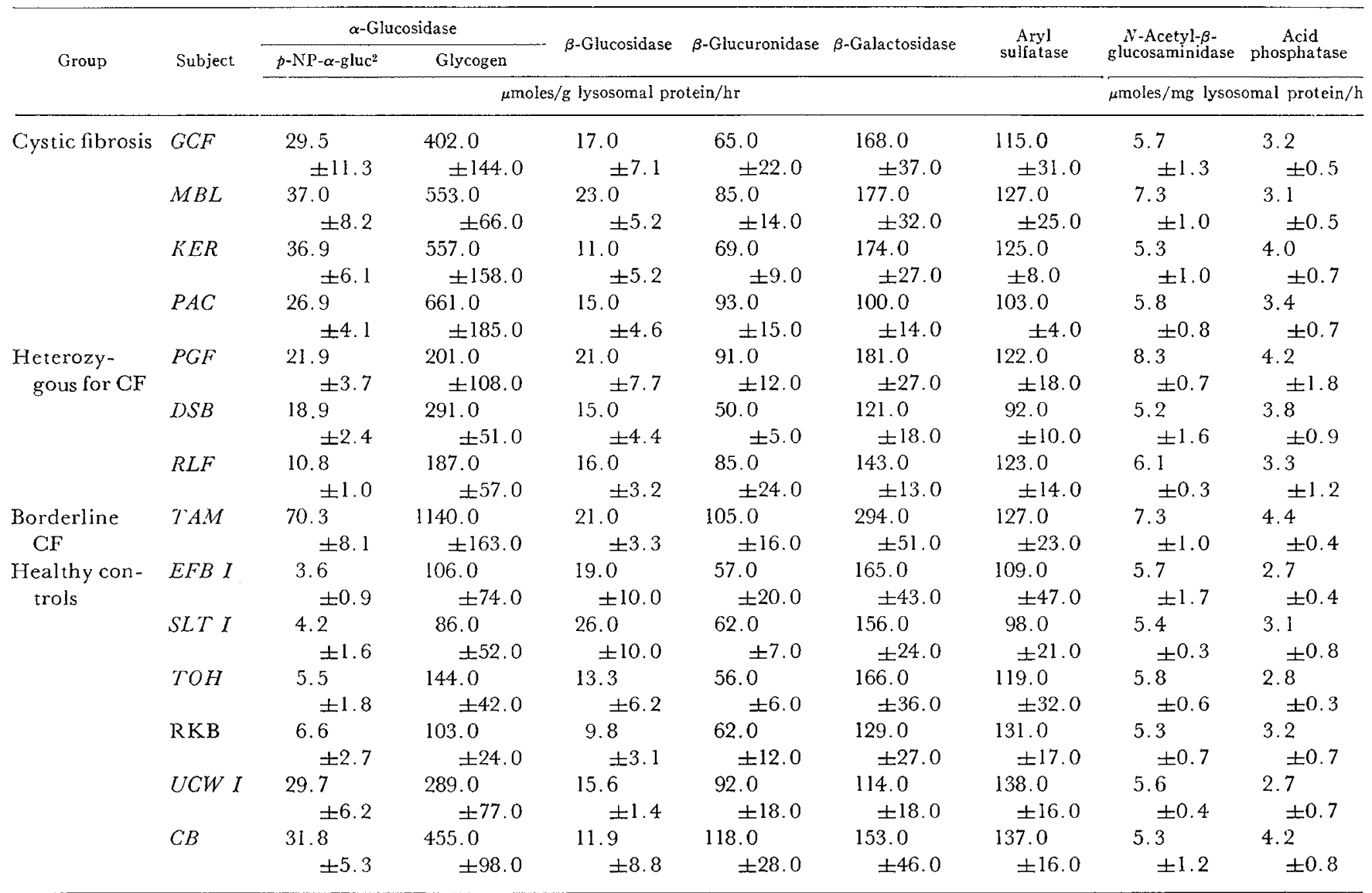

1 The values represent averages \pm sD obtained from four to six individual subcultures and cell fractionations in each cell line.

${ }^{2} p$-NP- $\alpha$-gluc: $p$-Nitrophenyl- $\alpha$-D-glucoside. 
Table II. Comparison between average specific activities of lysosomal enzymes in isolated lysosomes from cultured lymphoid cells obtained from patients with cystic fibrosis, heterozygotes, borderline, and con trol subjects

\begin{tabular}{|c|c|c|c|c|c|c|c|c|}
\hline \multirow{3}{*}{ Group } & \multicolumn{2}{|c|}{$\alpha$-Glucosidase } & \multirow{2}{*}{$\beta$-Glucosidase } & \multirow{2}{*}{$\beta$-Glucuronidase } & \multirow{3}{*}{$\beta$-Galactosidase } & \multirow{3}{*}{ Aryl sulfatase } & \multirow{2}{*}{$\begin{array}{c}N \text {-Acetyl- } \beta- \\
\text { glucosaminidase }\end{array}$} & \multirow{2}{*}{$\begin{array}{c}\text { Acid } \\
\text { phosphatase }\end{array}$} \\
\hline & $p$-NP- $\alpha$-gluc ${ }^{1}$ & Glycogen & & & & & & \\
\hline & \multicolumn{4}{|c|}{$\mu$ moles $/ \mathrm{g}$ lysosomal protein $/ \mathrm{hr}$} & & & \multicolumn{2}{|c|}{$\mu$ moles/mg lysosomal protein $/ \mathrm{h}$} \\
\hline \multicolumn{9}{|l|}{$\mathrm{CF}(4)^{2}$} \\
\hline Mean \pm SD & $\begin{array}{l}32.6 \\
\quad \pm 8.6\end{array}$ & $\begin{array}{l}543.5 \\
\quad \pm 163.3\end{array}$ & $\begin{array}{l}16.0 \\
\quad \pm 6.8\end{array}$ & $\begin{array}{l}78.0 \\
\quad \pm 18.7\end{array}$ & $\begin{array}{l}154.7 \\
\quad \pm 41.7\end{array}$ & $\begin{array}{l}117.2 \\
\quad \pm 22.0\end{array}$ & $\begin{array}{l}6.0 \\
\quad \pm 1.2\end{array}$ & $\begin{array}{l}3.4 \\
\quad \pm 0.7\end{array}$ \\
\hline Range & $19.0-49.1$ & $250.0-877.0$ & $6.8-29.0$ & $49.0-110.0$ & $79.0-158.0$ & $84.0-179.0$ & $3.7-8.5$ & $2.2-4.9$ \\
\hline \multicolumn{9}{|l|}{ Heterozygotes (3) } \\
\hline Mean $\pm \mathrm{sD}$ & $\begin{array}{l}17.2 \\
\quad \pm 5.5\end{array}$ & $\begin{array}{l}226.7 \\
\quad \pm 85.3\end{array}$ & $\begin{array}{l}17.4 \\
\quad \pm 5.8\end{array}$ & $\begin{array}{l}75.4 \\
\quad \pm 23.6\end{array}$ & $\begin{array}{l}148.5 \\
\quad \pm 32.0\end{array}$ & $\begin{array}{l}112.2 \\
\quad \pm 20.2\end{array}$ & $\begin{array}{l}6.5 \\
\pm 1.7\end{array}$ & $\begin{array}{l}3.8 \\
\quad \pm 1.3\end{array}$ \\
\hline Range & $10.1-27.3$ & $68.0-371.0$ & $8.1-33.0$ & $42.0-127.0$ & $95.0-218.0$ & $77.0-147.0$ & $4.1-8.8$ & $2.4-6.1$ \\
\hline $\begin{array}{l}\text { Total no. of de- } \\
\text { terminations }\end{array}$ & 15 & 15 & 15 & 15 & 15 & 15 & 15 & 15 \\
\hline \multicolumn{9}{|l|}{ Borderline (1) } \\
\hline Range & $60.5-78.2$ & $942.0-1358.0$ & $15.9-24.1$ & $68.0-127.0$ & $233.0-368.0$ & $90.0-148.0$ & $5.8-8.6$ & $4.0-4.8$ \\
\hline $\begin{array}{l}\text { Total no. of de- } \\
\text { terminations }\end{array}$ & 5 & 5 & 5 & 5 & 5 & 5 & 5 & 5 \\
\hline \multicolumn{9}{|l|}{ Control (6) } \\
\hline Mean \pm sD & $\begin{array}{l}13.8 \\
\quad \pm 12.2\end{array}$ & $\begin{array}{l}188.6 \\
\quad \pm 156.3\end{array}$ & $\begin{array}{l}15.3 \\
\quad \pm 8.3\end{array}$ & $\begin{array}{l}74.1 \\
\quad \pm 27.8\end{array}$ & $\begin{array}{l}145.9 \\
\quad \pm 36.5\end{array}$ & $\begin{array}{l}122.8 \\
\quad \pm 29.1\end{array}$ & $\begin{array}{l}5.6 \\
\quad \pm 1.0\end{array}$ & $\begin{array}{l}3.1 \\
\pm 0.6\end{array}$ \\
\hline Range & $1.4-40.4$ & $20.0-601.0$ & $6.7-39.0$ & $36.0-158.0$ & $85.0-230.0$ & $75.0-189.0$ & $2.5-8.0$ & $1.7-5.1$ \\
\hline $\begin{array}{c}\text { Total no. of de- } \\
\text { terminations }\end{array}$ & 29 & 30 & 27 & 31 & 28 & 29 & 30 & 30 \\
\hline
\end{tabular}

I $p$-NP- $\alpha$-gluc: $p$-Nitrophenyl- $\alpha$-D-glucoside, CF: Cystic fibrosis.

2 The number of individual cell lines is given in paren theses.

acid phosphatase, and one mitochondrial, malic dehydrogenase, were determined in the whole homogenates of the investigated cell lines. The results are presented in Table IV. As can be noted, a marked increase in the $\alpha$-glucosidase activity was found in the cystic fibrosis group, which is comparable to the values obtained in isolated lysosomes. However, because of the very low activity of this enzyme in whole homogenate of control cells which lies below the limit of the micromethod's sensitivity, a high standard deviation was obtained. There is no marked difference between the activities of acid phosphatase and malic dehydrogenase between controls and cystic fibrosis. Here again the borderline case has the highest value for $\alpha$-glucosidase activity.

\section{Discussion}

Danes and Bearn [9] studied cultured fibroblasts from patients with CF and heterozygous carriers of cystic fibrosis and observed an increased synthesis of mucopolysaccharides and their release into extracellular space. Matalon and Dorfman [22] noted an increase in total mucopolysaccharides with a distribution of the various fractions closely paralleling that observed in normal cell cultures. Johansen et al. [16] suggested that many tissues in cystic fibrosis are affected by a common defect which impairs cellular transport mechanisms and membrane permeability. As a result, excessive accumulation of secretory products and increased breakdown of cellular membrane components could occur, leading to an increased amount of mucopolysaccharides and other complex polyanionic macromolecules. This hypothesis is supported by the finding of Bartman et al. [2] that lysosomes in cultivated fibroblasts from patients with cystic fibrosis are more numerous and contain a larger amount of material. This accumulated material appeared in electron micrographs to consist of membranebound bodies, presumably lysosomes, containing a variable amount of material compatible with ultrastructural features of phospholipids and mucopolysaccharides. It is possible that this inability to metabolize excessive amounts of cellular substrates is enhanced in tissue cultures and induces the activity of lysosomal enzymes. 
Table III. Specific activity of mitochondrial enzymes in isolated mitochondria from cultured lymphoid cells, obtained from patients with cystic fibrosis, heterozygotes, borderline, and control subjects ${ }^{1}$

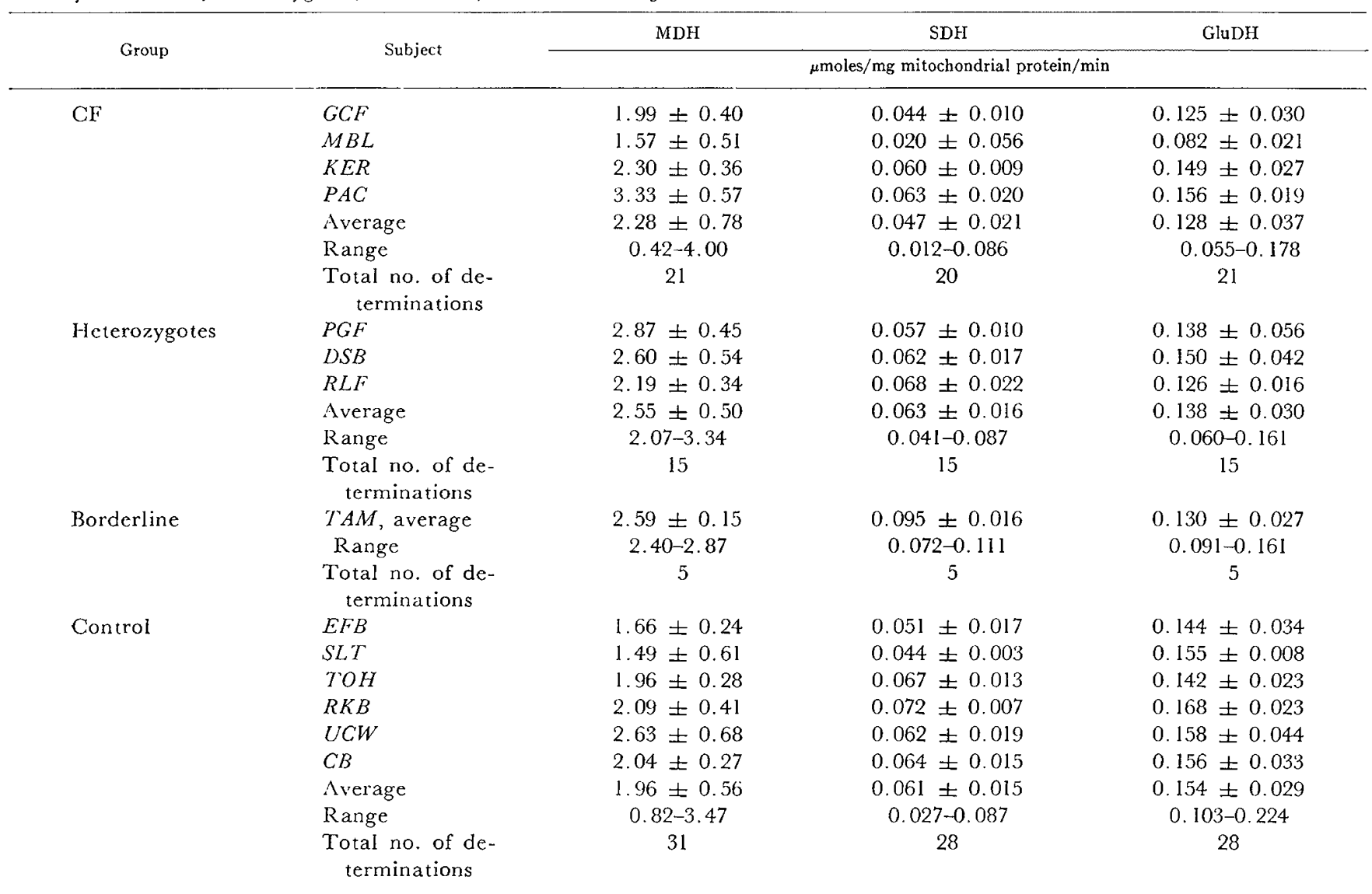

${ }^{1}$ The values represent averages \pm sD obtained from four to six individual subcultures and cell fractionations in each cell line. MDH: Malic dehydrogenase. SDH : Succinic dehydrogenase. GluDH: Glutamic dehydrogenase. CF: Cystic fibrosis.

In our study we found that $\alpha$-glucosidase activity was consistently and markedly higher in lysosomes from cultured lymphoid cells of four patients with cystic fibrosis, average 32.6 with a range of 19.0-49.1 $\mu$ moles/ $\mathrm{g}$ lysosomal protein $/ \mathrm{hr}$. The average value in the control group of six subjects was 13.2 with a range of 1.4$40.4 \mu$ moles $/ \mathrm{g}$ lysosomal protein $/ \mathrm{hr}$ with two individuals falling in the $\mathrm{CF}$ range.

The reason for these two high values in the clinically healthy individuals ( $U C W I$ and $C B$, Table $\mathrm{I}$ ) is difficult to interpret. It is possible that these two controls might be carriers of the CF gene, or these findings may indicate the wide range of "normal variation" for this enzyme. However, other studies dealing with brain and liver homogenates [24] did not show such a wide range of activity of this enzyme. Another possibility may be that we are measuring more than one enzyme or isoenzymes. Salafsky and Nadler [27] recently demonstrated the existence of different $\alpha$-glucosidases in various tissue
Table $I V$. Activities of $\alpha$-glucosidase, acid phosphatase, and malic dehydrogenase in whole homogenates of cell lines from cultured lymphoid cells obtained from patients with cystic fibrosis, heterozygotes, borderline, and control subjects ${ }^{1}$

\begin{tabular}{|c|c|c|c|}
\hline Group & $\begin{array}{c}\alpha \text {-Glucosidase, } \\
\mu \text { moles } / g \\
\text { protein } / \mathrm{hr}\end{array}$ & $\begin{array}{c}\text { Acid phosphatase, } \\
\mu \text { moles } / \mathrm{mg} \\
\text { protein } / \mathrm{hr}\end{array}$ & $\begin{array}{c}\mathrm{MDH} \\
\mu \text { moles } / \mathrm{mg} \\
\text { protein } / \mathrm{min}\end{array}$ \\
\hline $\mathrm{CF}(4)^{2}$ & $4.22 \pm 1.28$ & $1.32 \pm 0.38$ & $0.76 \pm 0.23$ \\
\hline Range & $2.80-7.40$ & $0.65-2.03$ & $0.40-1.15$ \\
\hline $\begin{array}{l}\text { Total no. of determi- } \\
\text { nations }\end{array}$ & 21 & 20 & 20 \\
\hline Hetcrozygote (3) & $2.52 \pm 1.06$ & $1.44 \pm 0.45$ & $0.90 \pm 0.29$ \\
\hline Range & $1.02-4.00$ & $0.90-2.24$ & $0.42-1.15$ \\
\hline $\begin{array}{l}\text { Total no. of determi- } \\
\text { nations }\end{array}$ & 15 & 15 & 15 \\
\hline Borderline (1) & $6.10 \pm 0.89$ & $1.26 \pm 0.35$ & $0.74 \pm 0.13$ \\
\hline Range & $5.00-7.50$ & $0.80-1.57$ & $0.54-0.87$ \\
\hline $\begin{array}{l}\text { Total no. of determi- } \\
\text { nations }\end{array}$ & 5 & 5 & 5 \\
\hline Control (6) & $1.50 \pm 1.60$ & $1.12 \pm 0.45$ & $0.69 \pm 0.18$ \\
\hline Range & $0-5.50$ & $0.39-2.52$ & $0.43-1.04$ \\
\hline $\begin{array}{l}\text { Total no. of cletermi- } \\
\text { nations }\end{array}$ & 31 & 31 & 31 \\
\hline
\end{tabular}

1 The values represent averages $\pm \mathrm{SD}$. $\mathrm{MDH}$ : Malic dehydrogenase. CF: Cystic fibrosis.

2 The number of cell lines is given in parenthescs. 
from the same patient, using inhibition by turanose and $\mathrm{pH}$ optima. In the present investigation we studied the effect of turanose [37] (3-O- $\alpha$-D-glucopyranosyl-D-fructose) as a specific and uncompetitive inhibitor of the lysosomal, as distinct from the neutral $\alpha$-glucosidase activity. We obtained the same degree of inhibition using 5 and $30 \mathrm{~mm}$ concentrations of turanose (30-32\% and $64-69 \%$ inhibition, respectively) with lysosomal homogenates of control and $\mathrm{CF}$ lysosomes. No inhibition was produced when pH 6.4 buffer was used. Me, however, did not study the optimal $\mathrm{pH}$ for this enzyme. Alternatively, the substrates which were employed may not allow proper differentiation of closely related enzymes, a possibility which was proven to be the case in Krabbe's disease [28]. The possibility exists of two types of healthy populations-one with low values and the other with high values for $\alpha$-glucosidase. Only the accumulation of more data would settle this question.

$\alpha$-Glucosidase is a lysosomal $(1 \rightarrow 4)$ glucosidase which causes extensive degradation of glycogen by stepwise attack on the terminal residues. In addition to the synthetic substrate we used the physiologic substrate glycogen and obtained the same elevated activity of $\alpha$-glucosidase in the patients with CF. Our findings are of special interest because of the recent observation of Pallavicini et al. [23] that the glycogen content of cultured fibroblasts from patients with cystic fibrosis is increased. The increased content of glycogen [23] might enhance the activity of $\alpha$-glucosidase. In this sense, however, there appears to be no clinical evidence of glycogen deposition, or any suggestion of disturbed glycogen metabolism in patients with cystic fibrosis. The absence of clinical symptoms of glycogen abnormalities does not necessarily mean that on a cellular level glycogen metabolism is not affected. To elucidate this fact, the biochemical determination of glycogen content in CF lymphoid cells might be of great interest. $\alpha$-Glucosidase activity determined in the whole homogenate of the investigated cell lines showed marked increase in the CF group comparable to the increase in isolate lysosomes. However, because of the very low activity of the enzyme in the whole homogenates of control cells a high standard deviation was obtained.

The estimation of other lysosomal enzyme activities, namely acid phosphatase, $\beta$-glucosidase, $\beta$-galactosidase, $N$-acetyl- $\beta$-glucosaminidase, aryl sulfatase, and $\beta$-glucuronidase, did not differ significantly in the patients with cystic fibrosis and controls. Griffin and Gibbs [13] reported that $\beta$-glucuronidase activity is decreased in short term cultures of PHA-stimulated CF lymphocytes on the 5 th day of culture, while $N$-acetyl- $\beta$-glucosamini- dase is decreased on the 7th day of culture. In our investigation we did not find any difference between the activity of these enzymes in the lysosomes of patients with CF and controls. However, in our study, continuously propagated lymphoid cell lines were used rather than short term cultures which had been established for only a brief period. Our cultures were grown for much longer periods of time, i.e., from 3 to 12 months. In fact, we did not find any variation in the enzyme activities in these stable cell lines during a 12-month period. Recently, Kraus et al. [17] and Benke [4] reported no difference in $\beta$-glucuronidase activity in control and $\mathrm{CF}$ fibroblasts.

The three enzymes investigated ( $\mathrm{SDH}, \mathrm{GluDH}$, and $\mathrm{MDH}$ ) in the mitochondrial fraction were similar in the cystic fibrosis and control cells. This result indicates that energy-producing metabolism is probably not affected in these cells which are growing in culture under optimal conditions.

In our experience, continuously grown cell lines of lymphocytes appear to offer a useful system for the study of cellular metabolism in cystic fibrosis and heterozygous carriers of the disease. The question, however, arises as to whether the consistent increase in $\alpha$-glucosidase activity is present only in vitro, after transformation and adaptation of cell growth, division, and metabolism to the specific conditions in continuous culture, or does it represent a metabolic abnormality existing in vivo? To answer this question it would be necessary to investigate the buffy coat cells of peripheral blood from patients with cystic fibrosis and controls. We are attempting to do this at present.

\section{Summary}

Seven lysosomal enzymes ( $\alpha$-glucosidase, $\beta$-glucosidase, $\beta$-galactosidase, $\beta$-glucuronidase, $\quad \mathrm{N}$-acetyl- $\beta$-glucosaminidase, aryl sulfatase, and acid phosphatase) and three mitochondrial enzymes (malic, succinic, and glutamic dehydrogenases) were studied in isolated lysosomes and mitochondria in cultured lymphoid cells from four patients with cystic fibrosis, three heterozygotes, one borderline case of cystic fibrosis, and six normal control subjects.

The lysosomes and mitochondria were isolated by differential and density gradient centrifugation. Among the lysosomal enzymes, only the activity of $\alpha$-glucosidase was markedly increased in the lysosomes of cultured lymphoid cells obtained from patients with cystic fibrosis. The activity of this enzyme was measured with two substrates ( $p$-nitrophenyl- $\alpha$-glucosidase and glycogen). 
In both determinations, the difference in activity was markedly higher. The mean values for $\alpha$-glucosidase activity, in micromoles per gram lysosomal protein per hour, were 32.6 (sD \pm 8.6 ) and 13.8 (sD \pm 12.2 ) for patients with cystic fibrosis and normal control subjects, respectively, with $p$-NP- $\alpha$-gluc as substrate, and 543.5 $(\mathrm{SD} \pm 163.3)$ and $188.6(\mathrm{SD} \pm 156.3)$, respectively, with glycogen as substrate. Activities of the remaining six lysosomal enzymes as well as of the mitochondrial enzymes did not show any difference between the lymphoid cells of patients with CF and normal control subjects.

It was concluded that this increase in the $\alpha$-glucosidase activity may suggest an impairment in cellular metabolism in cystic fibrosis.

\section{References and Notes}

1. Arrigoni, O., and Singer, T. P.: Limitations of the phenarine methosulphate assay for succinic and related dehydrogenases. Nature (London), 193: 1256 (1962).

2. Bartman, J., Wiesmann, U., and Blanc, W. A.: Ultrastructure of cultivated fibroblasts in cystic fibrosis of the pancreas. J. Pediat., 76: 430 (1970).

3. Beck, C., ANd TAPpel, A. L.: Rat liver lysosomal $\beta$-glucosidase: a membrane enzyme. Biochim. Biophys. Acta, 151: 159 (1968).

4. Benke, P. J.: Beta-glucuronidase and cystic fibrosis. New Engl. J. Med., 284: 731 (1971).

5. Bowers, W. E., Finkenstaedt, J. T., and DeDuve, C.: Lysosomes in lymphoid tissue. I. The measurement of hydrolytic activities in whole homogenate. J. Cell Biol., 32: 325 (1967).

6. Bücher, T., Luh, W., ANd PetTe, D.: Einfache und zusammengesetzte optische Tests mit Pyridinnucleatiden. In: Hoppe-Seyler and Thierfelder: Handbuch der physiologisch und pathologisch-chemischen Analyse, p. 292. (SpringerVerlag, Berlin, 1964).

7. DAhlQvist, A.: Method for assay of intestinal disaccharidases. Anal. Biochem., 7: 18 (1964).

8. Danes, B. S., and Bearn, A. G. : Cystic fibrosis of the pancreas. A study in cell culture. J. Exp. Med., 129: 775 (1969).

9. Danes, B. S., And Bearn, A. G. : Cystic fibrosis : distribution of mucopolysaccharides in fibroblast cultures. Biochem. Biophys. Res. Commun., 36: 919 (1969).

10. EAGle, H.: Amino acid metabolism in mammalian cell cultures. Science, 130: 432 (1959).

11. EgGstern, M., and Kreutz, F. H.: Vergleichende Untersuchungen zur Quantitativen Eiweissbestimmung in Liquor and Eiweissarmen Lösungne. Klin. Wochenschr. 33: 879 (1955).

12. Frieden, C.: Glutamate dehydrogenase. VI. Survey of purine nucleotide and other effects on the enzyme from various sources. J. Biol. Chem., 240: 2028 (1965).

13. Griffin, G. D., And Gibbs, G. E.: Lysosomal enzymes of cultured white blood cells in cystic fibrosis. Proc. Soc. Exp. Biol. Med., 137: 438 (1971).

14. Hосевоом, G. H. : Fractionation of cell components of animal tissues. In: S. P. Colowick and N. O. Kaplan: Methods in Enzymology, Vol. I, p. 16. (Academic Press, New York, 1955).
15. Hunter, M. J., And Commer ford, S. L. : Pressure homogenization of mammalian tissues. Biochim. Biophys. Acta, 47:580 (1961).

16. Johansen, P. G., Anderson, C. M., and Hadorn, B. : Cystic fibrosis of pancreas. A generalized disturbance of water and electrolytes movements in exocrine tissues. Lancet, $i: 455$ (1968).

17. Kraus, I., Antonowicz, I., Shah, H., Lazarus, H., and Shwachman, H.: Metachromasia and assay for lysosomal enzymes in skin fibroblasts cultured from patients with cystic fibrosis and controls. Pediatrics, 47: 1010 (1971).

18. Lagkart, R. Z., JR., And Eagle, H. : Requirement for growth of single cells. Science, 129: 252 (1959).

19. Lazarus, H., and Foley, G. E.: Cultivation of hematopoietic cells. In: G. Rothblat and V. Cristofalo: Growth, Nutrition and Metabolism of Cells in Culture, Vol. 2, p. 169. (Academic Press, New York, 1972).

20. Linhardt, K., and Walter, K.: Phosphatases. In: H. U. Bergmeyer: Methods on Enzymatic Analysis, p. 783. (Academic Press, New York, 1965).

21. Lowry, O. H., Rosebrough, N. E., Farr, A. L., AND Randall, R. J.: Protein measurement with the Folin phenol reagent. J. Biol. Chem., 193: 265 (1951).

22. Matalon, R., and Dorfman, A.: Acid mucopolysaccharides in cultured human fibroblasts. Lancet, $\ddot{i}: 838$ (1969).

23. Pallavicini, J. C., Wiesmann, U., Uhlendorf, W. B., and di Sant'Agnese, P. A.: Glycogen content of tissuc culture fibroblasts from patients with cystic fibrosis and other heritable disorders. J. Pediat., 77: 280 (1970).

24. Patel, V., Tappel, A. L., and O'Brien, J. S.: Hyaluronidase and sulfatase deficiency in Hurler's syndrome. Biochem. Med., 3: 447 (1970).

25. Rahman, Y. E., and Lindenbaum, A.: Lysosomes particles and subcellular distributions of polymeric tetravalent plutonium-239. Radiat. Res., 21: 575 (1964).

26. Roy, A. B.: Comparative studies on the liver sulphatases. Biochem. J., 68: 518 (1958).

27. Salafsky, I. S., AND Nadler, H. L.: Alpha-1,4 glucosidase activity in Pompe's disease. J. Pediat., 79: 794 (1971).

28. Suzuki, Y., and Suzuki, K.: Krabbe's globoid cell leukodystrophy: deficiency of galactocerebrosidase in serum, leukocytcs and fibroblasts. Science, 171: 73 (1971).

29. Talalay, P., Fishman, W. H., and Huggins, C.: Chromogenic substrates. II. Phenolphthalein glucuronic acid as substrate for the assay of $\beta$-glucuronidase activity. J. Biol. Chem., 166: 757 (1946).

30. Torres, H. N., and Olavarria, J. M.: Liver $\alpha$-glucosidases. J. Biol. Chem., 239: 2427 (1964).

31. Parr Instrument Company, Moline, IIl.

32. RC-2, Ivan Sorvall, Inc., Norwalk, Conn.

33. Spinco $\mathrm{L}$ with rotor SW 25.1, Beckman Instruments, Palo Alto, Calif.

34. Beckman Instruments, Palo Alto, Calif.

35. Branson Instruments Company, Stamford, Conn.

36. Koch-Light Laboratories, England.

37. Sigma Chemical Company, St. Louis, Mo.

38. Worthington Biochemical Corporation, Freehold, N. J.

39. Coleman 124, Perkin-Elmer, Maywood, Ill.

40. All procedures have been performed in accordance with the provisions set forth in the Declaration of Helsinki. 
41. The authors are indebted to Dr. George E. Foley for providing laboratory space, equipment, and guidance; to Dr. Herbert Lazarus for supplying cell lines; and to Mrs. S. Rich and Mr. Sin Kai Chang for their technical assistance.

42. This work was supported in part by a grant from the National Cystic Fibrosis Research Foundation and by Public Health
Service Grant no. AM-13385 from the National Institute of Arthritis and Metabolic Disease, National Institutes of Health.

43. Requests for reprints should be addressed to: HarRY SHWAGHMAN, M.D., 300 Longwood Avenue, Boston, Mass. 02115 (USA).

44. Accepted for publication July 18, 1972. 